\title{
A Conceptual Framework For Evaluating An Academic Department: A Systems Approach
}

Paul Green, Durban University of Technology, South Africa Stanley Hardman, University of KwaZulu-Natal, South Africa

\begin{abstract}
The purpose of this paper is to report on the development of a conceptual framework for the evaluation of an academic department as a service provider at a university of technology. A multi-methodological approach using action research, which involved a cyclical process between action and critical reflection, continuous refinement and understanding, was implemented. Critical to the study was the concept of emergence as a consequence of the interactions in the system. An analysis of systems methodologies and their applicability to evaluation signified a possible complementarity in their strengths with respect to their application in complex situations. A theoretical contribution of the study involved a unique combination of several existing techniques from different paradigms, which are mutually complementary into one intervention. Although the techniques and paradigms utilised in the study are not innovative, the combination and application thereof at a relatively new type of university in South Africa is, to the best of our knowledge, original.
\end{abstract}

Keywords: Evaluation; Systems Approach; Universities of Technology; Framework; South Africa

\section{INTRODUCTION}

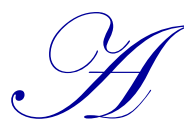

ccording to Spohrer, Maglio, Bailey and Gruhl (2007:71), service industries, including higher education, over the last two decades have become significant sectors in most economies of industrial societies. Although there has been this significant growth in service industries, there are no universally accepted definition of service, service productivity, quality, compliance, and innovation as all remain awkward to measure (Spohrer and Maglio, 2010:158). This is also true of the field of higher education. Sampson and Froehle (2006:330) are of the opinion that service delivery requires close interaction with a customer, particularly if the nature of the service requires customer participation and input. Tien and Berg (2003:113) advocate that service systems comprise both service providers and clients working together. This is also the case with higher education institutions such as universities.

According to Spohrer et al (2007:72), universities are service providers that aim to transform student knowledge. This transformation is dependent upon contracts, relationships, and other interactions among students and universities, including curricula, tuition fees and work-study arrangements. Education, as a service, is committed to satisfying the educational needs of its clients by creating education services required by learners and not constraining them to accept existing educational facilities. Diversified educational provision does not guarantee a high quality of education, but different educational services are in a constant state of competition. Vargo and Lusch (2004:2) define services as the application of specialized competencies (knowledge and skills) through deeds, processes, and performances for the benefit of another entity or the entity itself. This implies that almost any purposeful system within a business or governmental entity, including higher education institutions, can be viewed as a service system, as competencies are being applied to something for someone.

Universities of technology are relatively new in South Africa. A definition of a university of technology (UOT) is found in du Pré (2009:15) - "It is not the use of technology within a university which classifies it as a 
technological university, but rather the interweaving, focus and interrelation between technology and the nature of a university which constitutes a technological university." At a UOT, the focal point is on the study of technology from the perspective of diverse fields of study, rather than a particular field of study. The aim of technology, then, is to improve the lives of human beings. Likewise, the technology espoused by du Pré (2009) is synonymous with the competencies outlined by Vargo and Lusch (2004). du Pré (2009:16) claims that at a UOT, all teaching and learning programmes and research projects are related to technology. The technology is the qualifying factor inherent to all academic activities.

Winberg (2004:40) suggests that the fear that universities of technology will lower academic standards emanates from a narrow vision of knowledge and scholarship. On the contrary, universities of technology have produced knowledge and scholarship in applied fields, and particularly in areas of technology innovation, technology management, and technology exchange. In the transformation from a "technikon" to a UOT, the brand of these institutions was lost due to the name change. In addition, it was recognized that the concept of a university of technology was not well-known in South Africa.

\section{THE NEED FOR A MULTI-METHODOLOGICAL APPROACH TO ADDRESS THE EVALUATION OF AN ACADEMIC DEPARTMENT AS A SERVICE PROVIDER}

A university system may be deemed a complex system, associated with "messy problems", particularly in the area of evaluation, and there is a need for a systemic pluralist methodology to address the evaluation of service quality. A review of the literature indicates that no single approach has successfully addressed the complexities associated with evaluation of service quality at a university. Mingers and Brocklesby (1997:490) advocate that in order to make the most effective contribution in dealing with the richness of the real world, it is desirable to go beyond using a single methodology to generally combining several methodologies, in whole or in part, and possibly those from different paradigms. Robey (1996:401) argues that a diversity of research methods and paradigms within the discipline is a positive source of strength. Jackson (1992:84) mentions the inability of a single approach to account for complexity, to handle power-related issues in problem contexts, and to bring about true emancipation for all those involved in the problem context; he recommends, instead, a pluralist approach.

Following are some of the reasons which justify the need for a systems approach to university management and evaluation. Habib and Parekh (2000) and Hay \& Fourie (2002) highlight the fragmented systems inherited from the pre-1994 government(s) of the apartheid system, which led to a vertically and horizontally fragmented system along provincial level and racial lines. Wyngaard and Kapp (2004) and CHE (2000) discuss the inequities and disjunctions of the systems. Wyngaard and Kapp (2004) expound on the incoherent and poor articulation between various types of further and higher education institutions. Hay and Fourie (2002) and CHE (2000) concur that the distribution of resources and subsidies amongst further and higher education institutions is unequal. Bunting (1994:3) discusses the poor throughput rates by tertiary institutions. Reddy (1998) cites declining enrolment in some institutions, migration of students between institutions, and non-participation in further and higher education. Wyngaard and Kapp (2004) accentuate the impact of legislation - South African Qualifications Authority (SAQA), National Qualifications Framework (NQF), Skills Development Act, Skills Development Levy, Labour Relations Act, Affirmative Action - which changed the profile of institutions and which resulted in increased salaries and the expansion of basic fringe benefits to all members of staff. This context necessitated the implementation of a systems approach in higher education and, more specifically, in the evaluation of an academic department as a service provider at a UOT. In addition, Reynolds (2012:7) asserts that systems thinking is gaining prevalence in the field of evaluation, largely to assess complex interventions.

\section{APPROACHES TO BE INCLUDED IN THE CONCEPTUAL FRAMEWORK}

The framework is, in itself, not a concrete tool, but rather the model could be used as a basis for further adaptations, amendments and application. The desired outcome is multi-fold - to entice theoretical discourse, for practical application regarding evaluation of service quality, to enhance focussed thinking in the arena of evaluation and service, to provide a platform for potential building blocks, and to sensitize practitioners of evaluation to emergent properties in a system. Therefore, Mingers' (2001:241) arguments - that different research methods focus on different aspects of reality, and subsequently, a richer understanding of a research topic will be gained by 
combining several methods together into a single piece of research - are supported. The approaches shown in Figure 1 have been included in the framework and justification for the selection of the approaches is provided. They have been placed in a pyramid with Critical Systems Thinking providing the foundation of the framework. Soft Systems Methodology (SSM), Viable System Model (VSM) and System Dynamics (SD) were used because of the strengths of these methodologies. The techniques of SSM included rich pictures which assisted in understanding the problem. Causal Loop Diagrams, a powerful technique of SD, provided an analysis of the system and its interaction with its sub-systems. VSM was utilised for its strength in organisational systems and, finally, WSM for its specific applicability to service organisations; i.e., academic departments.

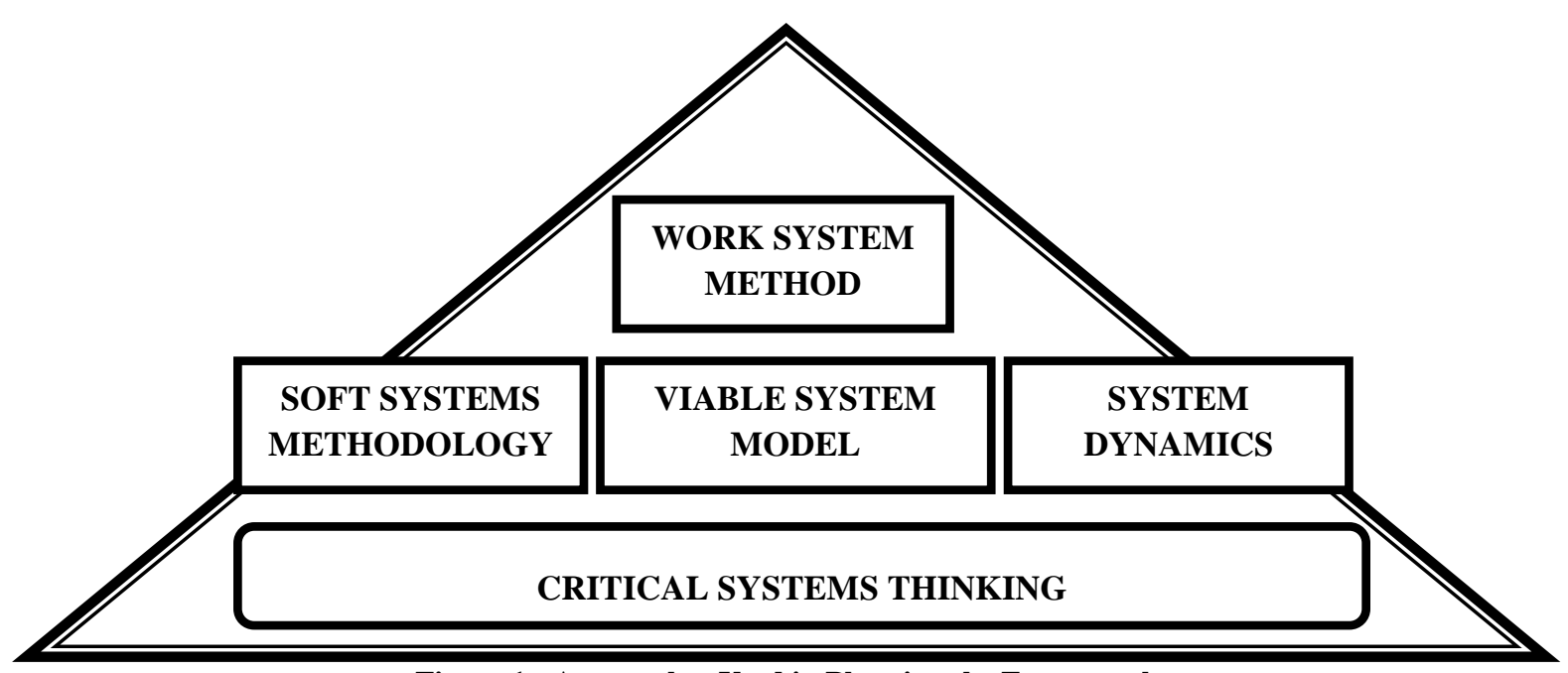

Figure 1: Approaches Used in Planning the Framework

\section{Critical Systems Thinking}

Critical Systems Thinking (CST) was selected in planning the framework, as the basis of the study is to evaluate service quality and CST provides an element of critique which is required in the evaluation process. CST provides an apt philosophical and theoretical foundation for an intervention in complex situations like evaluation of service quality of an academic department at a university. Having identified the determinants of service quality and its implications for a university, Ulrich's Critical Systems Heuristics (CSH) twelve boundary judgements are an ideal checklist which would allow for normative content of the system to be unpacked and for qualitative analysis. The questions were grouped according to Ulrich's $(1996,1998)$ sources of influence - motivation, control, knowledge, and legitimacy. Answers to these boundary questions will attempt to make sense of a situation by making clear the boundaries that limit our understanding. These boundaries inform our thinking about situations and systems. People often view situations differently, simply because they frame the situations differently. CSH provides a tool for understanding the multiple perspectives people bring into situations and, in total, the 12 questions prompt an understanding of the bigger picture.

The next candidate that was considered in the adoption of the framework was Soft Systems Methodology.

\section{Soft Systems Methodology}

The notion of Soft Systems Methodology (SSM) emerged as a result of dissatisfaction with the limitations of hard systems thinking (Jackson, 2003:182 and Khisty, 1995:94). The purpose of SSM was to produce a systems methodology capable of dealing with soft problems. Checkland (2000:8) asserts that SSM illustrates that in all problem situations, people are trying to take purposeful action in spite of all the ambiguity, uncertainty, disagreement and conflict. The SSM technique that was considered for the evaluation framework was the use of rich pictures because of their expressive power and ability to represent the structure, processes, climate, people and issues expressed by people and conflicts, as well as CATWOE analysis. Petkov, Petkova, Andrew and Nepal (2007:1619) cite that rich pictures are cartoon-like images that capture the structure of a problem, the processes 
involved and the relationships between structure and processes. Checkland and Scholes (1999:24) believe rich pictures are a better means for recording relationships and connections than is linear prose. The meaning of the CATWOE mnemonic is listed in Table 1 together with its meaning in the context of the improvement of service quality of an academic department at a UOT.

Table 1: CATWOE and Its Meaning in the Context of Improvement of Service Quality at an Academic Department

Customers: The customers, beneficiaries or victims of the provision of the service at a university of technology.

Actors: The people that are involved in the system at the university.

Transformation: The process that transforms inputs into outputs.

World-view: The viewpoint from which the transformation should take place.

Owners: Those in the university that have decision-making authority - those who can stamp out unsatisfactory service delivery.

Environmental constraints: The environment includes those factors that will impinge on the situation, and over which the actors and owners have no control.

The Viable System Model (VSM) was the next candidate adopted as this model was developed with a goal of understanding organisations and how to make recommendations to improve organisational effectiveness.

\section{The Viable System Model}

The main theory underlying VSM is that for an organisation to be viable; that is, its ability to survive within a changing environment, it must undertake particular activities and there must be certain relations between them. VSM developed after studying how human beings are organised as viable systems (see Rosenhead and Mingers, 2001:267) and it is against this background, together with the university being labelled as a large organisation, that VSM has been selected as a candidate in the development of the conceptual framework. A university exists within, and is coupled to, an environment or community which it serves. The university is responsible for undertaking various activities with respect to the environment; that is, its primary activities which would include, amongst others, teaching and learning. To survive, however, the university must be able to regulate these activities.

A fundamental premise of VSM is the notion of recursion. Viable systems are embedded within viable systems. A university is a viable system of the education system but itself consists of departments that could be viable, and within them courses and students. Although, at a university, there are a number of systems, the question is then posed, "is the student recognised as a self-sufficient learning system" within a bigger system? Does the university create sufficient opportunities and space for the learner to operate and engage with the other systems of the university? The test is, could this activity in principle be taken out of the organisation and have its own separate existence? If so, it is a primary activity and no university can be deemed a university without having students. Thus, activities such as marketing, administration, personnel and the information system of a university, are arguably not primary activities since they would have no reason for existence without the students. The concept of recursive or nested viable systems implies the conscious choice of the level of analysis; Beer (1985) calls this the system in focus. The system in focus in this study is the interaction the student has with the university.

The fourth candidate adopted was Systems Dynamics, developed by Forrester (1975) who argued that the behaviour of systems, regardless of their level, resulted from underlying structures of flows, delays, information and feedback relations.

\section{System Dynamics}

Gregory (2009:11) states that System Dynamics (SD) is an approach that involves building a model that captures the dynamic nature of systems and aims to identify the underlying structure of social systems. Fredericks, Deegan, and Carman (2008:252) posit that SD is increasingly being recognised as a useful tool for evaluation purposes. The use of SD within multimethodology is most often combined with SSM (see Cavana, Lee, Bennet, Taylor 1996:183 and Coyle and Alexander, 1997:206). In the context of this study, SD is used to provide context, explain competing goals and to identify important feedback processes and the potential for unintended consequences. 
Causal Loop Diagramming (CLD), which is one of the primary SD techniques used in the course of the action research, is utilized in this study. It is a technique used in SD (Forrester, 1975) to understand the dynamic complexity of organisational behaviour. Burns and Musa (2001) mention that one of the purposes of using CLD is to capture the dynamic cycles of influence that would serve to pinpoint where leverage points in the system exist. In this action research, CLDs were used to enhance thinking around the links between sub-systems, and the possible causal impacts of policy changes, as well as to gain insight into complex systems and causal structures. In particular, they were used to understand the behavioural implications of students at a university. This information was then used to determine main points of leverage in various sub-systems to help determine the appropriate strategies for implementation.

The university is an open system which largely portrays the environmental context to which it belongs. There are various systems within a university that are interrelated and intertwined working to render a service to its stakeholders. The operation of the university as a system is never static but rather because of its open nature, having influences from multiple stakeholders, has a dynamic nature. The university having a number of external influences, including government, businesses, donors, accreditation and evaluation bodies, parents, etc., can be regarded as a social system.

The SD model provides useful insight into the relationships within the system, identifying causal loops, and understanding their dynamic nature. Although teaching and learning has been identified as the pinnacle in the relationship between the university and the student, there are other elements, particularly social elements, which influence the behaviour and these, are normally counterintuitive. The process of teaching and learning at a university is affected by the various accreditation and evaluation bodies that to some degree, dictate the nature of the course. The labour market arguably would also impinge upon the social system of the university which is also influenced by the throughput rates at each university.

The next candidate that has been selected in the development of the framework for its applicability to service organisations is Steven Alter's Work System Method.

\section{The Work System Method}

A relatively recent approach to systems thinking is the Work System Method. According to Alter (2007:34), the work system method (WSM) represents a systems approach as it describes a situation as a system consisting of interacting components that operate together to accomplish a purpose. Alter (2002:90) states that the WSM is a broadly applicable set of ideas that use the concept of "work system" as the crucial point for understanding, analyzing, and improving systems in organizations. According to Alter's (2006:16) analysis, as part of the work system method, typically begins with using a simple and widely applicable tool called a work system snapshot. The purpose of the work system snapshot is to clarify the scope of the work system and identify the most important things that it produces for its customers. Table 2 is a work system snapshot of a typical UOT operation in South Africa. 
Table 2: Work System Snapshot of a Learner's Service Experience at a University

\begin{tabular}{|c|c|c|c|}
\hline \multicolumn{2}{|l|}{ Customers } & \multicolumn{2}{|r|}{ Products And Services } \\
\hline \multicolumn{2}{|c|}{$\begin{array}{ll}\text { - } & \text { Students } \\
\text { - } & \text { Staff (Academic \& Administration - Institutional Support) } \\
\text { - } & \text { Parents } \\
\text { - } & \text { Government } \\
\text { - } & \text { Management }\end{array}$} & \multicolumn{2}{|c|}{$\begin{array}{ll} & \text { Tuition } \\
- & \text { Administrative Services } \\
\text { - } & \text { Auxiliary services (Counselling, Health Care, } \\
& \text { Library, Financial Aid, Housing, Cafeteria) }\end{array}$} \\
\hline \multicolumn{4}{|c|}{ Work Practices (Major Activities Or Processes) } \\
\hline \multicolumn{4}{|c|}{$\begin{array}{l}\text { - Initially a potential learner will make application via the Central Applications Office (CAO). } \\
\text { - Alternatively learners will arrive at the institution looking for possible spaces at an academic department. } \\
\text { - Academic staff will scan an applicant's statement of results received from the Department of Education to determine if he } \\
\text { or she meets the minimum entrance requirements. } \\
\text { - If yes, learner can return on date of registration. } \\
\text { - } \quad \text { If no, learner informed that he or she does not meet the entrance requirements and is informed of alternatives. } \\
\text { - } \text { the learner to have the minimum deposit. } \\
\text { - Student registers and receives academic timetable and told when to return for orientation and start of lectures. } \\
\text { Major activity is the lectures/facilitation/teaching and learning/assessments. Interaction between Academic Staff and } \\
\text { - Students } \\
\text { Administrative interaction with: } \\
\text { - Departmental Secretary } \\
\text { - Finance } \\
\text { - Library } \\
\text { - Security }\end{array}$} \\
\hline Participants & \multicolumn{2}{|l|}{ Informati } & \\
\hline $\begin{array}{ll}\text { - } & \text { Students } \\
\text { - } & \text { Staff (Academic \& } \\
& \text { Administration) } \\
\text { - } & \text { Parents/Donors } \\
\text { - } & \text { Student Representative Council } \\
& \text { (SRC) } \\
\text { - } & \text { Government } \\
\text { - } & \text { Employers } \\
\end{array}$ & \multicolumn{2}{|c|}{$\begin{array}{ll}\text { - } & \text { Matric/School leaving } \\
\text { - } & \text { Certificate } \\
\text { Qualifications from previous } \\
\text { - } & \text { tertiary institutions } \\
\text { - } & \text { Financial Information } \\
\text { - } & \text { Lecture nocuments } \\
& \text { Lenterial }\end{array}$} & $\begin{array}{ll}- & \text { Computers } \\
- & \text { Integrated Tertiary S } \\
& \text { (ITS) } \\
\text { - } & \text { Networks } \\
- & \text { Bank card machines }\end{array}$ \\
\hline
\end{tabular}

After applying the work system snapshot to the university to ascertain the important things that it produces for its customers, the next step is to consider Steven Alter's Service Value Chain Framework (Figure 2). The framework assisted in delineating the responsibilities of the service provider and the customer.

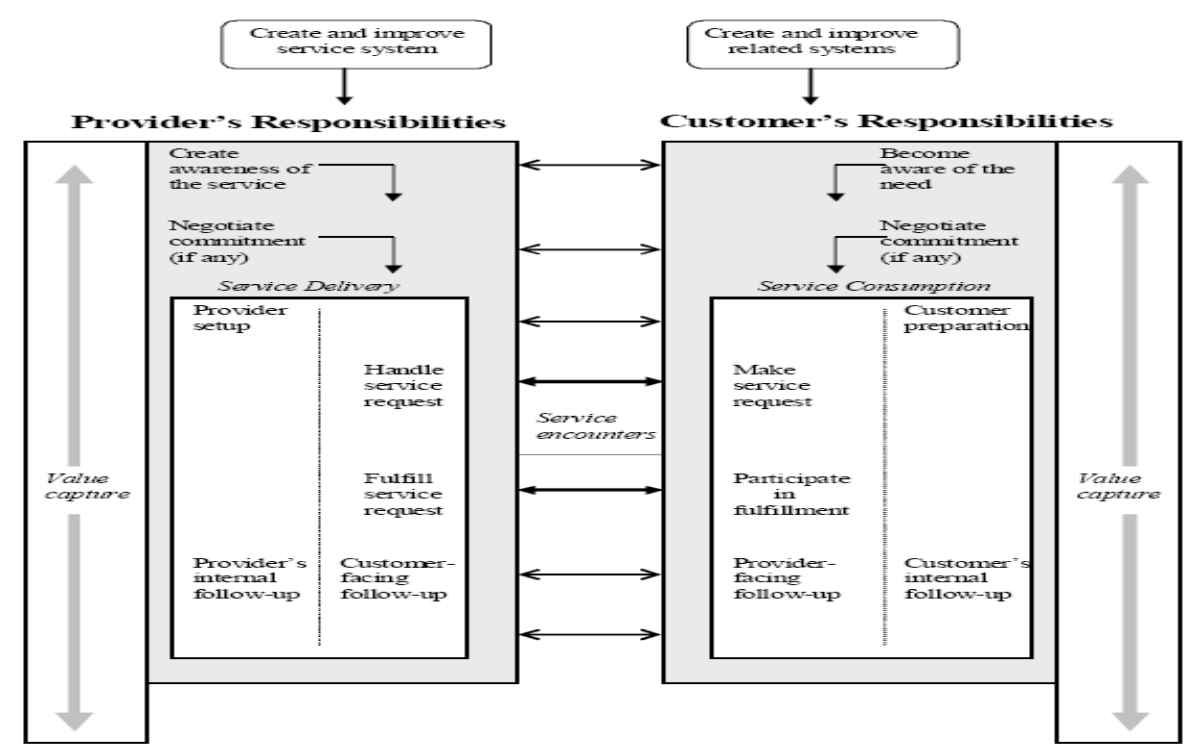

Figure 2: Service Value Chain Framework (Adapted from Alter, 2007, 2008a) 
The various methodologies employed in the development of the framework have been discussed. The following section investigates the potential synergies and, importantly, the elimination of probable methodological conflicts.

Schwaninger (2004:415) is of the opinion that the challenge of complex organisational issues requires the joining of forces between the VSM and SD methodologies. It is argued that these cannot be completely separated because they are closely interlinked. SD and VSM have each established models and methods capable of addressing issues the other is not equipped to deal with. According to Schwaninger, Rios and Ambroz (2004:16), using a combination of SD and VSM methodologies, is complementary because:

- Their objectives are in harmony.

- Their methodologies are individually incomplete, mutually exclusive, but collectively exhaustive or at least comprehensive.

- $\quad$ Both are highly generic and therefore applicable to a great variety of situations.

- $\quad$ Both SD and VSM are rooted in the Systems Approach.

Looking at the combination of methodologies and paradigms adopted in this study, the conceptual framework gains support from empirical research previously undertaken (see Haslett and Sankaran, 2009:2). In addition, there have been many other studies which have also adopted a multi-methodological approach drawing upon the strengths of each paradigm (see Petkova \& Petkov, 2012:1), which discusses the comparison of the work system method and soft systems methodology. Another study also reveals the experiences of combining multiple criteria decision-making and techniques from soft systems approaches for decision support in complex problemsolving (see Petkov, Petkova, Andrew \& Nepal, 2007:1616). Munro and Mingers (2002:369) discuss the move toward a pluralistic approach of combining several methods within an intervention to form a multi-methodology, and note the particular combinations which are most commonly used. From the above, it is evident that the approach adopted in this study is empirically sound, since it is established upon fundamental research backgrounds.

The following section discusses the conceptual framework.

\section{A CONCEPTUAL FRAMEWORK FOR THE EVALUATION OF AN ACADEMIC DEPARTMENT AS A SERVICE PROVIDER AT A UNIVERSITY OF TECHNOLOGY}

The conceptual framework proposed is based upon the theoretical underpinning of Critical Systems Thinking following on the work of system experts Jackson, Flood, Mingers, Midgley and, more recently, Alter. The framework harnesses the strengths of SSM techniques, Critical Systems Heuristics, Viable System Method and System Dynamics and connects these with the extension of the Work System Method to service organisations.

Following on the work of Mingers (1997:431), the conceptual framework is developed from multiple perspectives represented in Multimethodology. Mingers (1997:431) asserts that a fully comprehensive intervention needs to be concerned with the three different worlds - material, personal and social - which were conceptualized in the work of Habermas $(1984,1987)$. The techniques utilised in this study, which address the three worlds reflecting facets of the problem in the framework, are shown in Table 3.

Table 3: Mapping of Possible Techniques Suitable for the Evaluation of an Academic Department Onto the Three Worlds of Habermas (Following Mingers, 1997)

\begin{tabular}{|ll|ll|}
\hline \multicolumn{1}{|c|}{ Social World } & \multicolumn{1}{c|}{ Personal World } & \multicolumn{1}{c|}{ Material World } \\
\hline$\bullet$ & SSM (Rich pictures \& CATWOE) & $\bullet$ & SSM (Rich pictures \& CATWOE) \\
$\bullet$ & SD (Causal Loop Diagrams) & $\bullet$ & WSM (Work System Snapshot) \\
$\bullet$ & CSH (12 boundary questions) & $\bullet \quad$ SD (Causal Loop Diagram) & $\begin{array}{l}\text { VSM (Viable Systems - the student } \\
\text { as a self-sufficient learning system) } \\
\text { WSM (Service responsibility Tables } \\
\text { \& Service Value Chain Framework) }\end{array}$ \\
\hline
\end{tabular}

Mingers (1997:433) warns that it is not intended that methodologies are slotted into particular boxes like the system of systems methodologies (see Jackson and Keys, 1984) but rather that they are mapped across all the different areas to which they can contribute. Secondly, the precise placing of a particular methodology or technique 
is debatable. However, this is also one of the desired outcomes of the framework, which is to invoke debate. Thirdly, the multimethodology approach includes the possibility of utilizing only parts of methodologies.

The overall philosophical foundations of the framework are based on critical systems thinking, not only for its commitment to pluralism, but also for its obedience to the emancipatory idea. This implies that the framework will also provide a voice for the students regarding evaluating service quality.

The notion of commensurability of paradigms is of particular importance in this study as Kuhn (1970) claims that the issue of paradigm choice can never be unequivocally settled by logic and experiment alone. Pluralism has to accept and manage a certain degree of incompatibility between paradigms on the theoretical level. A possible solution is suggested by Midgley (1997) and supported by Jackson (2003) and was based on earlier work undertaken by Wendy Gregory regarding what is termed as discordant pluralism. Gregory (2009) believes that the differences between paradigms/methodologies should not be rationalized by the use of a meta-theoretical structure but rather the 'discordance' of methodologies should be preserved and lessons of learning should be drawn from it. Therefore, the problem of paradigm incommensurability can be addressed by complementing our thinking about paradigms with a theory of how researchers from different backgrounds can learn from each other, but only on their own terms (Petkov, Petkova, Nepal and Andrew, 2007). The latter implies that communication between them, and hence between paradigms, is possible.

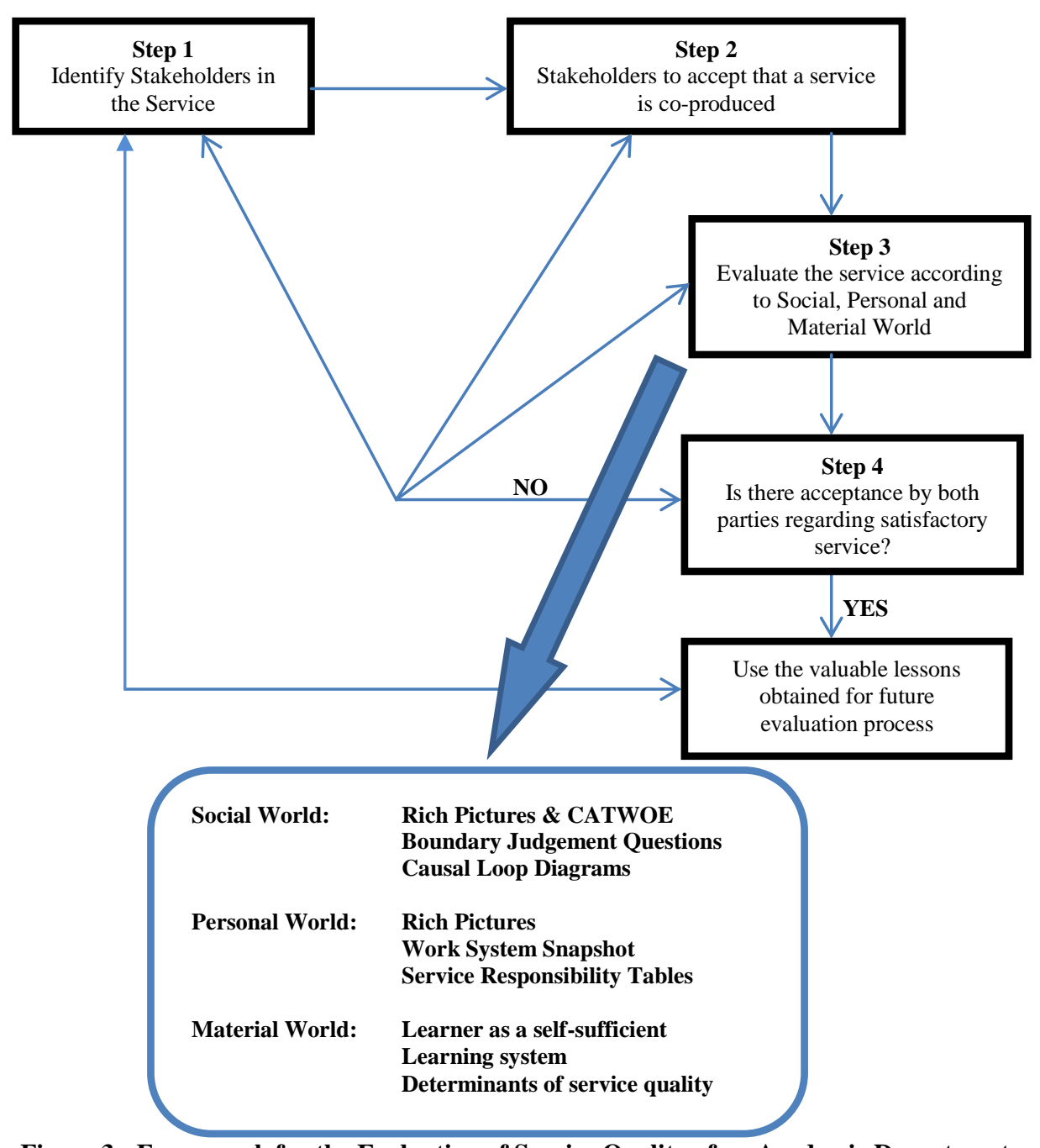

Figure 3: Framework for the Evaluation of Service Quality of an Academic Department 
Another interesting view on the issue of paradigm incommensurability is the idea proposed by Deetz (1996) that the four discourses defined by him are not well formulated with clear boundaries, and as such cannot be considered paradigms. Under such conditions, it is a given that different discourses may be in dialogue. It can then be ascertained that Deetz (1996) and both Midgley (1997) and Jackson (2000) support, in their separate arguments, the idea of certain forms of paradigm mediation and a combination of all these ideas can be accepted as sufficient justification of the use of techniques from different methodologies based on different paradigms. A combination of the above arguments provides a resolution to the issue of paradigm incommensurability in the framework that is being developed.

\section{CONCLUSION}

The proposed framework is an action research framework with the philosophical underpinnings nested in Critical Systems Thinking and based on the work of Checkland and Holwell (1998). The conceptual framework presents a combination of SSM, SD, VSM, WSM within a multimethodology framework of Mingers (1997:420) and the latest extension of the Work System Method to service organisations of Steven Alter (2008b:6). Jackson (1997:19) proposes a coherent pluralism in management sciences, within the framework of Critical Systems Practice, and this framework aims to follow that call by involving the potential actors of the university.

The framework was prepared from the perspectives of the body of knowledge within the evaluation of service quality in higher education, service organisations, complex systems and systems thinking. Following on the work of Mingers and Gill (1997:412), it was shown that the formulation of the framework could be based on a metatheoretical approach to mixing methods and techniques from different paradigms, called Multimethodology. Soft Systems Methodology was used as the dominant methodology following the justification that SSM has a tradition of being used for evaluation purposes (see Gregory and Jackson, 1992). However, the proposed framework for the evaluation of an academic department as a service provider at a university of technology is significantly different from the work of Gregory and Jackson, since the researcher's framework uses a simplified form of SSM, which is enhanced by CSH, SD, VSM and WSM, making it more applicable to the problem of concern.

\section{ACKNOWLEDGEMENT}

This work is based on the research supported in part by the National Research Foundation of South Africa - Unique Grant No. 86437.

\section{AUTHOR INFORMATION}

Paul Green, is a lecturer at the Durban University of Technology, South Africa. He is a $\mathrm{PhD}$ candidate and his research interests include Systems Thinking, Evaluation, Service Quality and Universities of Technology. E-mail: paulg@dut.ac.za (Corresponding author)

Dr. Stanley Hardman, is a senior lecturer at the Graduate School of Business and Leadership at the University of KwaZulu-Natal. He maintains a research interest in practitioner research and in partnerships which he currently focuses on the professional development of Local Economic Development practitioners.

\section{REFERENCES}

1. Alter, S. (2002) The work system method for understanding information systems and information systems research. Communications of the AIS, 9(6), pp 90-104.

2. Alter, S. (2006) The Work System Method: Connecting People, Processes, and IT for Business Results. Larkspur, CA: Work System Press.

3. Alter, S. (2007) Service Responsibility Tables: A New Tool for Analyzing and Designing Systems. AMCIS 2007, Americas Conference of Information Systems, Keystone. Aug. 9-12, 2007.

4. Alter, S. (2008a) Service System Fundamentals: Work System, Value Chain, and Life Cycle, IBM Systems Journal, 47(1) pp 71-85. 
5. $\quad$ Alter, S. (2008b) "Service System Innovation" IFIP (International Federation of Information) Working Group 8.2 Conference on IT and Change in the Service Economy, Toronto, Canada, August 2008.

6. Beer, S. (1985) Diagnosing the System for Organisation. Chichester: Wiley.

7. Burns, J. and Musa, P. (2001) Structural Validation of Causal Loop Diagrams. Paper presented at the System Dynamics Society $19^{\text {th }}$ Annual Conference, Atlanta, Georgia, 23-27 July 2001.

8. Bunting, I. (1994) A legacy of inequality: Higher Education in South Africa. Cape Town: UCT Press.

9. Cavana, R.Y., Lee, M.W., Bennett, J. and Taylor, R.J. (1996) Possum and gorse control on a farm woodlot: A System Dynamics Analysis. Asia-Pacific Journal of Operational Research, 13(2), pp 181-207.

10. Checkland, P. (2000). Soft systems methodology: a 30 year retrospective. Systems Research and Behavioural Science, 17(S1), S11-S58.

11. Checkland, P.B. and Holwell, S. (1998). Information, Systems and Information Systems - making sense of the field. Chichester: Wiley.

12. Checkland, P. and Scholes, J. (1999). Soft Systems Methodology in Action. Chichester: Wiley.

13. Council on Higher Education (CHE) (2000). Towards a new higher education landscape: meeting the equity, quality and social development imperatives of South Africa in the 21st century. Report of the Shape and Size of Higher Education Task Team. Pretoria: Department of Education.

14. Coyle, R.G. and Alexander, D.W. (1997) Two Approaches to Qualitative Modelling of a Nation's Drugs Trade. System Dynamics Review, 13(3), pp 205-222.

15. Deetz, S. (1996) Describing Differences in Approaches to Organisational Science: Rethinking Burrel and Morgan and their Legacy. Organisational Science, 7(2), pp 190-207.

16. du Pré, R. (2009) The Place and Role of Universities of Technology in South Africa. Bloemfontein, South Africa: South African Technology Network.

17. Forrester, J.W. (1975) World Dynamics. $2^{\text {nd }}$ Edition. Waltham, MA: Pegasus Communication.

18. Fredericks, K.A., Deegan, M. and Carman, J.G. (2008) Using system dynamics as an evaluation tool: An experience from a demonstration program for people with developmental disabilities. American Journal of Evaluation, 29(3), pp 251-267.

19. Gregory, A.J. (2009) Scoping a systems-based method for organisational evaluation. Proceedings from the 53rd Annual Meeting of the International Society for Systems Science (ISSS) 2009, 12-17 July, Brisbane, Australia, pp 1-17.

20. Gregory, A.J. and Jackson, M.C. (1992) Evaluating organisations: A systems and contingency approach. Systems Practice, 5.

21. Habermas, J. (1987) The Theory of Communicative Action Vol. 2: Lifeworld and System: A Critique of Functionalist Reason. Oxford: Heinemann.

22. Habermas, J. (1984) The Theory of Communicative Action Vol. 1: Reason and Rationalisation of Society. London: Heinemann.

23. Habib, A. and Parekh, A. (2000) Transforming South Africa's University System: The Case for Strategic Mergers. Perspectives in Education, 18(3), pp 39-51.

24. Haslett, T. and Sankaran, S. (2009) Applying Multi-Methodological Systems Theory to Project Management. Proceedings of the 53rd Annual Meeting of the International Society for the Systems Sciences. University of Queensland, Brisbane, Australia, July, 12-17.

25. Hay, H.R. and Fourie, M. (2002) Preparing the way for mergers in South African higher and further education institutions: An investigation into staff perceptions. Higher Education, 44(1), pp 115-131.

26. Jackson, M.C. (2003) Systems Thinking: Creative Holism for Managers. Chichester: John Wiley and Sons.

27. Jackson, M.C. (1997) Towards Coherent Pluralism in Management Science. Lincoln School of Management Working Paper 16, University of Lincolnshire \& Humberside, Lincoln, UK.

28. Jackson, M.C. (1992) An Integrated programme for Critical Thinking in Information Systems Research. Journal of Information Systems, 2, pp 83-95.

29. Jackson, M.C. and Keys, P. (1984) Towards a System of System Methodologies. In Flood, R.L., and Jackson, M.C. (Eds.). Critical Systems Thinking: Directed Readings. New York: Wiley.

30. Khisty, D. (1995) Soft Systems Methodology as Learning and Management Tool. Journal of Urban Planning and Development, 21(3), pp 92.

31. Kuhn, T.S. (1970). The Structure of Scientific Revolutions. $2^{\text {nd }}$ Edition. Chicago: University of Chicago Press. 
32. Midgley, G. (1997) Mixing methods: developing systemic intervention. In: Mingers J, Gill A (eds). Multimethodology: The theory and Practice of Combining Management Science Methodologies. Chichester: Wiley, pp 249-290.

33. Mingers, J. (2001). Combining IS Research Methods: Towards a Pluralist Methodology. Information Systems Research, 12(3), pp 240-259.

34. Mingers, J. (1997) Multi-paradigm Multimethodology, in Mingers, J. and Gill, J., (Eds.), Multimethodology: The Theory and Practice of Integrating OR and Systems Methodologies, Chichester: Wiley, pp 1-22.

35. Mingers, J. and Brocklesby, J. (1997). Multimethodology: towards a framework for mixing methodologies. Omega, 25(5), pp 489-509.

36. Mingers, J. and Gill, A. (1997) Multimethodology. The Theory and Practice of Combining Management Science Methodologies. England: John Wiley \& Sons Ltd.

37. Munro, I. and Mingers, J. (2002) The use of multimethodology in practice - Results of a survey of practitioners. Journal of Operational Research Society, 59(4), pp 369-378.

38. Petkov, D., Petkova, O., Andrew, T. and Nepal, T. (2007) Mixing Multiple Criteria Decision Making with soft systems thinking techniques for decision support in complex situations. Decision Support Systems, 43(4), pp 1615-1629.

39. Petkova, O. and Petkov, D (2012) The Work System Method and Soft Systems Methodology - Some Comparisons. Proceedings from UK Academy for Information Systems Conference 201. Paper 40.

40. Reddy, J. (1998) Regional consortia, partnerships, mergers and their implications for the transformation of the South African higher education system. Unpublished Report.

41. Reynolds, M. (2012) Equity-focused development evaluation using critical systems thinking. Proceedings from the $10^{\text {th }}$ European Evaluation Society Biennial Conference: Evaluation in the networked society: new concepts, new challenges, new solutions. 3-5 October 2012, Helsinki.

42. Robey, D. (1996) Research Commentary: Diversity in Information Systems Research: Threat, Promise and Responsibility. Information Systems Research, 7(4), pp 400-408.

43. Rosenhead, J. and Mingers, J. (2001) Rational Analysis for a Problematic World Revisited. Problem Structuring Methods for Complexity, Uncertainty and Conflict. Chichester: John Wiley \& Sons Ltd.

44. Sampson, S.E. and Froehle, C.M. (2006) Foundations and Implications of a Proposed Unified Services Theory. Production and Operations Management, 15(2), pp 329-343.

45. Schwaninger, M. (2004) Methodologies in Conflict: Achieving Synergies Between System Dynamics and Organizational Cybernetics. Systems Research and Behavioural Science, 21, pp 411-431.

46. Schwaninger, M., Rios, J.P. and Ambroz, K. (2004) System Dynamics and Cybernetics: A Necessary Synergy. Proceedings from International System Dynamics Conference, Oxford, July 2004.

47. Spohrer, J. and Maglio, P.P. (2010) Towards a science of service systems. Handbook of service science. Service science: Research and innovation in the service economy, pp 157-194.

48. Spohrer, J., Maglio, P.P., Bailey, J. and Gruhl, D. (2007) Steps Towards a Science of Service Systems. Computer, 40(1), (Jan. 2007), pp 71-77.

49. Tien, J.M. and Berg, D. (2003) A case for service systems engineering. The Journal of Systems Science and Systems Engineering, 12(1), pp 113-128.

50. Ulrich, W. (1996) A primer to critical systems heuristics for action researchers. Centre for Systems Studies: University of Hull, Hull.

51. Ulrich, W. (1998) Systems thinking as if people mattered: critical systems thinking for citizens and managers. Working paper No 23, Lincoln School of Management, University of Lincolnshire \& Humberside, Lincoln.

52. Vargo, S.L. and Lusch, R.F. (2004) Evolving to a new dominant logic for marketing. Journal of Marketing, 68(1), pp 1-17.

53. Winberg, C. (2004) Becoming a University of Technology, Sediba sa Thuto: Academic Journal of Vaal University of Technology, Vol 1, pp 38-54.

54. Wyngaard, A. and Kapp, C. (2004) Rethinking and re-imagining mergers in further and higher education: a human perspective. South African Journal of Higher Education, 18(1), pp 185-201. 
NOTES 